\title{
Pemanfaatan Smartphone Untuk Meningkatkan Kreatifitas Kube Posdaya Permata Bunda Di Kecamatan Rumbai Pesisir
}

\author{
Vitriani $^{1^{*}}$, Lega Putri Utami ${ }^{2}$, Willyansyah ${ }^{3}$ \\ ${ }^{1}$ Fakultas Keguruan Ilmu Pendididikan, Universitas Muhammadiyah Riau \\ ${ }^{2}$ Fakultas Teknik, Universitas Muhammadiyah Riau \\ ${ }^{3}$ Manajemen Informatika, AMIK Tri Dharma \\ email : vitriani@umri.ac.id
}

\begin{abstract}
Rumbai Pesisir Regency has several Joint Business Groups (KUBE). Among them is KUBE Posdaya Permata Bunda. KUBE is managed by creative housewives who have a high desire to work to help the family economy. KUBE manufactures various handicrafts from used plastic materials including bags, fruit containers, tissues. The purpose of this activity is to provide information and training to mothers in theUBUBU Posdaya Permata Bunda on the use of smatphone as a promotional site for products manufactured by KUBE Posdaya Permata Bunda. The implementation of this activity began with the introduction of various kinds of promotional media through social media such as Facebook, Instagram, WA and other social media. The activity continued with creating a social media account and how to promote crafts through social media. The target of this service is to contribute to the community through the use of smartphones to increase production sales.
\end{abstract}

Keywords: KUBE, Plastic Waste, Technology

\begin{abstract}
Abstrak
Kecamatan Rumbai Pesisir memiliki beberapa Kelompok Usaha Bersama (KUBE). Diantaranya adalah KUBE Posdaya Permata Bunda. KUBE ini dikelola oleh ibu-ibu rumah tangga kreatif yang mempunyai keinginan tinggi untuk berkarya guna membantu perekonomian keluarga. KUBE ini menghasilkan beragam kerajinan tangan dari bahan plastik bekas antara lain tas, tempat buah, tissue. Tujuan pelaksanaan kegiatan ini adalah memberikan informasi dan pelatihan kepada ibu ibuKUBE Posdaya Permata Bunda tetang pemanfaatan smatrphone sebagai tempat promosi produ yang dihasilkan oleh KUBE Posdaya Permata Bunda. Pelaksanaan kegiatan ini dimulai dengan pengenalan macam macam media promosi melalui sosial media seperti facebook, instagram, WA dan sosial media lainnya. Kegiatan dilanjutkan dengan pembuatan akun media sosial dan bagaimana cara mempromosikan hasil kerajinan melalui media sosial. Target dari pelaksanaan pengabdian ini adalah memberikan kontribusi kepada masyarakat melalui penggunaan smartphone guna meningkatkan penjualan hasil produksi.
\end{abstract}

Kata Kunci: KUBE, Limbah Plastik, Tekmnologi

\section{PENDAHULUAN}

Kelompok Usaha Bersama (KUBE) adalah suatu kelompok usaha yang terdiri dari beberapa orang anggota, yaitu ibu-ibu rumah tangga kreatif yang ada di Kecamatan Rumbai Pesisir. Mereka berkumpul, bekerja bersama-sama untuk mengembangkan diri melalui beberapa kegiatan. Dari berbagai kegiatan yang telah dilakukan bersama mendapat suatu peluang yang bisa dikembangkan untuk dijadikan usaha, maka lahirlah Kelompok Usaha Bersama (KUBE) yang diberinama KUBE Posdaya Pertama Bunda. KUBE Posdaya Permata Bunda merupakan Kelompok Usaha Bersama ibu-ibu rumah tangga yang 
menghasilkan berbagai jenis kerajinan tangan dari bahan plastik bekas. Beberapa produk yang telah dihasilkan antara lain: tas, dompet, wadah permen, keranjang, tempat tisu dan tempat buah. Permasalahan Mitra adalah masih kekurangan informasi mengenai peluang pasar atas aneka produk yang diproduksi. Tujuan pengabdian ini adalah memberikan informasi dan pelatihan penfaatan media smartphone sebagai tempat pemasaran.

\section{METODE PENGABDIAN}

Pelaksanaan kegiatan ini terdiri dari dua tahap, yaitu metode ceramah dan metode praktek penggunaan smartphone. Metode ceramah berisikan perkembangan pemasaran, dimana tempat berjualan tidak perlu lagi memiliki tempat, cukup dengan memiliki smarthpone dan internet serta barang yang akan diproduksikan. Selain itu juga diperlihatkan ide ide menarik dan kreatif dalam pengolahan limbah plastik. Metode kedua adalah praktek langsung pemasaran produk menggunakan smarthpone yaitu dengan cara memandu pembuatan akun dan cara pemasaran di media sosial. lain.

Tahap pelaksanaan kegiatan antara

1. Tahap Persiapan

Sebelum melaksanakan kegiatan, tim pelaksana melakukan koordinasi dengan masyarakat dan menentukan waktu pelaksanaan kegiatan.

2. Tahap Kegiatan

Tahap pelaksanaan kegiatan dibagi menjadi 2 tahap

a. Ceramah

Pada tahap ini masyarakat diberi pengetahuan tentang teknologi smartpone dan pemanfaatannya antara lain video di youtube tentang ide kreatif pemanfaatan limbah plastik.

b. Demonstrasi

Pada tahap ini masyarakat disuruh membuka smartpone dan membuat akun media sosial seperti instagram dan facebook KUBE mereka.
Setelah selesai tahap pembuatan akun, masyarakat diajarkan bagaimana cara memposting dan memasarkan produk melalui akun media sosial yang telah dibuat.

\section{HASIL DAN PEMBAHASAN}

Tahap awal dalam pelaksanaan pengabdian adalah melakukan survey tempat kegiatan dengan melakukan berbagai pertimbangan, maka KUBE posdaya permata bunda di daerah rumbai menjadi pilihan untuk pelaksnaan kegiatan. Pada tahap ini tim pelaksana melakukan diskusi dan dialog dengan ketua dan anggota posdaya tentang hambatan dan permasalahan yang dihadapi.

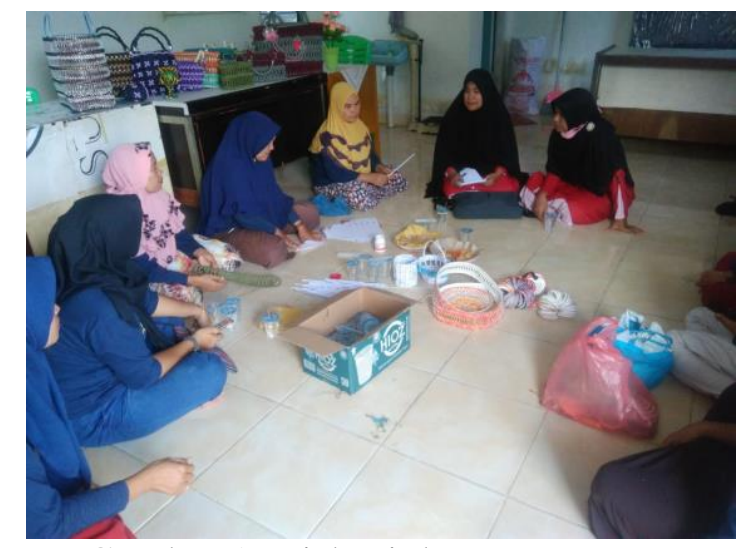

Gambar 1. Diskusi dengan anggota kelompok Posdaya Permata Bunda.

Berikutnya adalah tahap pelaksanaan kegiatan. Tahap pelaksanaan kegiatan diawali dengan kesepakatan dengan ketua dan anggota jadwal pelaksanaan kegiatan. Pada tahap ini terdiri dari dua sesi. Sesi pertama merupakan sesi presentasi dan diskusi tentang pemanfaatan teknologi smartpone dalam pemasaran. Smartpone tidak hanya dapat dimanfaatkan sebagai sarana berkomunikasi saja tetapi juga dapat dijadikan sarana promosi produk dan barang. Dengan smartpone masyarakat juga dapat belajar tentang ide ide produk yang dpat mereka buat dari limbah plastik. 


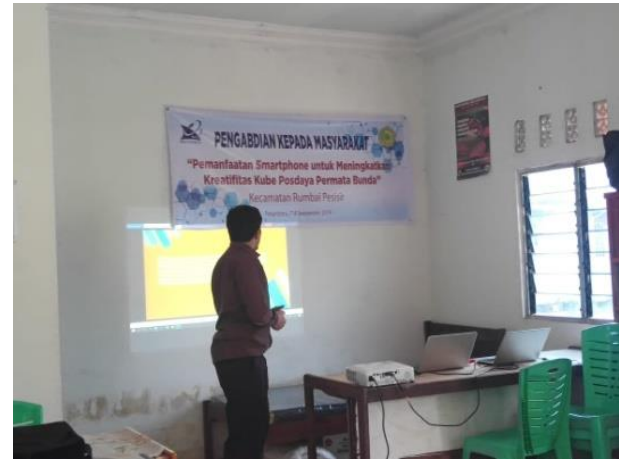

Gambar 2. Penyampaian materi

Sesi kedua diisi dengan Pelaksanaan pembuatan akun sosial KUBE permata bunda dan cara memasarkan produk melalui akun media sosial seperti FB, Instagram dan WA. (Gambar 3). Masyarakat selama ini hanya memanfaatkan smartphpone sebagai media komunikasi. Mereka tidak mengetahui cara memasarkan produk melalui media sosial.

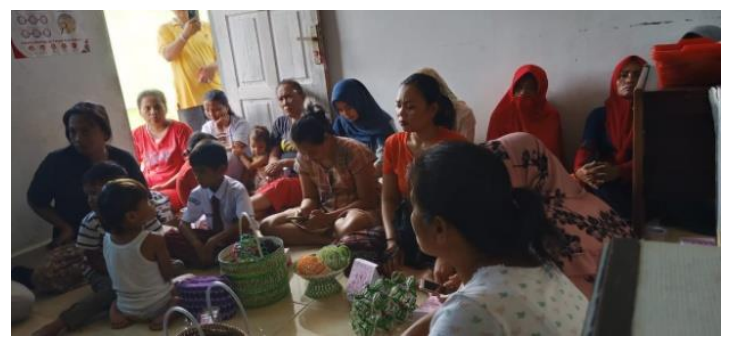

Gambar 3. Bimbingan Pembuatan akun media sosial.

\section{SIMPULAN}

Simpulan dari kegiatan pengabdian diatas adalah.

1. Kegiatan pelatihan ini mampu memberikan informasi dan wawasan baru kepada masyarakat tentang pemanfaatan smartphone.

2. Pemasaran produk kerajinan dari limbah plastik yang di buat oleh KUBE posdaya Permata Bunda tidak hanya dapat dipasarkan dengan cara konvensional seperti ke toko toko dan mengikuti pameran, tetapi dengan memanfaatkan akun media sosial

3. Peserta dapat menjual produk mereka di rumah saja serta dapat meningkatkan jumlah penjualan.

\section{UCAPAN TERIMA KASIH}

Terimakasih kepada LPPM UMRI yang telah mendanai kegiatan pengabdian ini. Terimakasih kepada masyarakat Rumbai Pesisir khususnya Posdaya Permata Bunda.

\section{DAFTAR PUSTAKA}

[1]. Abdillah, F. (2012). Hubungan Kohesivitas Kelompok dengan Intensi Turnover pada Karyawan. Journal of Social and Industrial Psychology. Diunduh dari http://journal.unnes.ac.id/sju/index.p $\mathrm{hp} / \mathrm{sip}$.

[2]. Agung, M. I. (2013). Dinamika kelompok perspektif psikologi sosial. Dipublis di buku Psikologi Sosial 2 oleh Mira, dkk., 2013. Pekanbaru: AlMujahadah Press.

[3]. Alvi, I. (2010). Hubungan kohesivitas kelompok dengan tingkat religiusitaspengurus OSIS MAN Kandangan Kabupaten Kediri (Skripsi). Malang:Universitas Islam Negeri.

[4]. Amalia, P. A. (2009). Hubungan kohesivitas kelompok dengan komitmenorganisasi pada karyawan (Sktipsi). Surakarta: UniversitasMuhammadiyah Surakarta

[5]. Azwar, S. (2015). Penyusunan Skala Psikologi. Yogyakarta : Pustaka Pelajar.

[6]. Caron, A. V., Brawley, L. R., \& Widmeyer. (2009). Dalam Jurnal Development ofa Cohesion Questionnaire for Youth: The Youth Sport Environment Questionnaire. Journal of sport and exercise psychology. Human kinetics,Inc.

[7]. Moekijat. (2010). Manajemen Sumber Daya Manusia. Bandung: CV Mandar Maju

[8]. Priyatno. (2014). SPSS 22 Pengolahan Data Terpraktis. Yogyakarta: Andi Offset 